\title{
Meloxicam affects the inflammatory responses of bovine mammary epithelial cells
}

\author{
M. O. Caldeira, ${ }^{1,2}$ R. M. Bruckmaier, ${ }^{1}$ and O. Wellnitz ${ }^{1 *}$ \\ ${ }^{1}$ Veterinary Physiology, Vetsuisse Faculty, University of Bern, 3001 Bern, Switzerland \\ ${ }^{2}$ Graduate School for Cellular and Biomedical Science, University of Bern, 3012 Bern, Switzerland
}

\begin{abstract}
Nonsteroidal anti-inflammatory drugs are used as supportive therapy with antimicrobial treatments for mastitis in cows to alleviate pain of the inflamed mammary gland. They act mainly by inhibition of cyclooxygenases. Meloxicam (MEL) is a drug designed for cyclooxygenase-2 selectivity, which is upregulated upon inflammation, acting as a key enzyme for the conversion of arachidonic acid to prostaglandins. Although some studies in dairy cows showed positive results in recovery from mastitis when MEL was added to the treatments, direct effects of MEL on the immune system of mastitic cows are unknown. The aim of this study was to investigate effects of MEL on the immune response of bovine mammary epithelial cells (MEC) with or without simultaneous immune stimulation by pathogen-associated molecular patterns of common mastitis pathogens. Mammary epithelial cells from 4 cows were isolated and cultured. To evaluate dose effects of MEL, MEC were challenged with or without $0.2 \mu \mathrm{g} / \mathrm{mL}$ lipopolysaccharide (LPS; serotype O26:B6 from Escherichia coli) with addition of increasing concentrations of MEL $(0,0.25,0.5,1.0,1.5$, or 2.0 $\mathrm{mg} / \mathrm{mL}$ ). The addition of MEL prevented the increase of mRNA expression of key inflammatory factors in LPS-challenged MEC in a dose-dependent manner. To investigate the effects of MEL on pathogen-specific immune responses of MEC, treatments included challenges with LPS from $E$. coli and lipoteichoic acid from Staphylococcus aureus with or without $1.5 \mathrm{mg} / \mathrm{mL}$ MEL for 3, 6, and $24 \mathrm{~h}$. Meloxicam prevented the increase of mRNA abundance of key inflammatory mediators in response to LPS and lipoteichoic acid, such as tumor necrosis factor, serum amyloid $\mathrm{A}$, inducible nitric oxide synthase, and the chemokines IL- 8 and CXC chemokine ligands 3 and 5 . The prostaglandin $\mathrm{E}_{2}$ synthesis in challenged and nonchallenged cells was reduced by MEL
\end{abstract}

Received March 15, 2019.

Accepted July 2, 2019.

*Corresponding author: olga.wellnitz@vetsuisse.unibe.ch within $24 \mathrm{~h}$. Furthermore, MEL reduced the viability and consequently the total RNA yield of the cells. However, mRNA abundance of apoptosis-related enzymes was not affected by any treatment. Meloxicam had clear dose-dependent effects on the immune response of MEC to pathogen-associated molecular patterns of common mastitis pathogens by preventing increased expression of important factors involved in inflammation. This nonsteroidal anti-inflammatory drug also has detrimental effects on cell viability. How these effects would influence the elimination of pathogens from an infected mammary gland during mastitis therapy with meloxicam needs to be further investigated.

Key words: meloxicam, mastitis, nonsteroidal antiinflammatory drug, mammary gland

\section{INTRODUCTION}

The lactating mammary gland is frequently subject to challenges by contagious and environmental pathogens, which can induce mastitis. Dairy animals that usually have a high incidence of mastitis are often treated with nonsteroidal anti-inflammatory drugs (NSAID) in combination with antimicrobial agents showing positive results in reducing pain of the inflamed tissue and fever (Fitzpatrick et al., 2013).

During the early stages of inflammation, the activation of the mammary gland innate immune system is initiated by the recognition of exogenous pathogenassociated molecular patterns (PAMP), such as LPS from gram-negative bacteria or lipoteichoic acid (LTA) from gram-positive bacteria. The response of the mammary immune system to the different PAMP shows different patterns (Wellnitz et al., 2011, 2013) and mimics the course of the disease induced by the different bacteria.

The initiation of the immune response includes the activation of the nuclear factor $\kappa \mathrm{B}$ pathway, which controls the regulation and production of proinflammatory cytokines involved in host defense (Lawrence, 2009; Tang et al., 2012). Tumor necrosis factor (TNF) is one of these proinflammatory cytokines that triggers an 
increase in further cytokine production and generation of chemokine release, such as IL-8, CXC chemokine ligand (CXCL) 3 and CXCL5 (Holdsworth and Gan, 2015). Furthermore, inflammation-associated cytokines activate the acute-phase response - for example, the increase in concentrations of serum amyloid A (SAA), an acute-phase protein known for its fast and steep increase upon bacterial infection and its involvement in LPS binding and clearance (Cheng et al., 2018).

Cytokines also stimulate the release of arachidonic acid from the cell membrane phospholipids by phospholipase $\mathrm{A}_{2}$ (Kawahara et al., 2015). Cyclooxygenases (COX) mediate the conversion of arachidonic acid to prostaglandin (PG; Ricciotti and FitzGerald, 2011). Two isoforms of COX are known: COX-1 is involved in the permanent homeostatic regulation and expressed in almost all cells, whereas COX-2 is activated upon provoked inflammation (Gilroy et al., 1999). Prostaglandin $\mathrm{E}_{2}$ mediates fever (Ushikubi et al., 1998) and plays a role in increasing pain associated with acute inflammation (Tilley et al., 2001).

Nonsteroidal anti-inflammatory drugs block the COX enzymes, leading to a decreased synthesis of bioactive PG. Meloxicam (MEL) is a drug designed with COX-2 selectivity to avoid the common side effects of the inhibition of COX-1; it reduces the cytoprotective prostacyclin synthesis and, therefore, gastrointestinal irritation and renal toxicity (Engelhardt et al., 1996a). In rats with induced inflammation, MEL showed a strong inhibition of $\mathrm{PGE}_{2}$ biosynthesis (Engelhardt et al., 1996b). In dairy cattle, NSAID showed beneficial effects on recovery when used with antibiotic therapy (McDougall et al., 2009) in mild to moderate mastitis cases. Cows treated with $0.5 \mathrm{mg} / \mathrm{kg}$ MEL were less likely to be culled from the herd due to impairment of the mammary function and had increased probability of bacteriological cure and improved subsequent fertility (McDougall et al., 2016). Still, no information is available on how the administration of MEL plays a role in the mammary gland immune function.

The first objective of this study was to investigate the immunological responses of bovine mammary gland epithelial cells (MEC) to different doses of MEL with or without LPS stimulation through the modulation of mRNA expression of key pro- and anti-inflammatory genes and protein synthesis. The second objective was to evaluate whether the MEC immune responses to MEL are PAMP specific (LPS and LTA) and whether they change over time ( 3 to $24 \mathrm{~h}$ postchallenge). We hypothesized that the addition of MEL to MEC would diminish, in a dose-dependent manner, the expression of immune mediators involved in the inflammatory processes triggered after the challenge with different PAMP. Results should provide indications of the poten- tial influence of the mammary immune response during mastitis therapy with the established NSAID MEL.

\section{MATERIALS AND METHODS}

\section{Preparation of Cell Cultures}

Primary cultures of mammary epithelial cells of clinical healthy mammary glands (SCC $<100 \times 10^{3}$ cells/ $\mathrm{mL}$ ) from 4 Holstein dairy cows were established as described by Wellnitz and Kerr (2004). We designed the study to detect a change of 1 threshold cycle $(\mathbf{C t})$, which is often shown after a challenge with different pathogenic components with a significance level of 0.05 and a power of 0.80 , giving a sample size of 4 per treatment. To cope with potential omission of single wells due to technical reasons, treatments were performed in duplicate.

Cells cryopreserved in Dulbecco's modified Eagle's medium (DMEM)/F12 (Sigma-Aldrich, Buchs, Switzerland), 20\% fetal bovine serum (FBS; SigmaAldrich), and 10\% dimethyl sulfoxide (Sigma-Aldrich) were thawed, washed with DMEM/F12 medium, and centrifuged at $40 \times g$ at $23^{\circ} \mathrm{C}$ for $3 \mathrm{~min}$. The MEC of the 4 cows were cultured in separate flasks with growth medium [DMEM/F12 with 10\% FBS, 1\% Pen-Strep $(10,000$ units of penicillin and $10 \mathrm{mg}$ of streptomycin/ $\mathrm{mL}$; Sigma-Aldrich), and $1 \%$ ITS $(0.5 \mathrm{mg} / \mathrm{mL}$ insulin, $0.5 \mathrm{mg} / \mathrm{mL}$ apo-transferrin, and $0.5 \mu \mathrm{g} / \mathrm{mL}$ sodium selenite; Sigma-Aldrich)] at $37^{\circ} \mathrm{C}$ with $5 \% \mathrm{CO}_{2}$. After 1 passage, cells from 4 cows were seeded separately at a density of $220 \times 10^{3}$ cells/well in 12-well cell culture plates (BD Biosciences, Allschwil, Switzerland) and incubated until approximately 70 to $80 \%$ confluency. For the experiment, the medium was changed to DMEM/ F12 with 3\% FBS, 1\% Pen-Strep, and 1\% ITS.

\section{Treatments}

Experiment 1: Immune Responses of MEC to Different Doses of MEL. Immediately before the treatment, MEL (meloxicam sodium salt hydrate; Sigma-Aldrich) was dissolved in sterile double-distilled $\mathrm{H}_{2} \mathrm{O}$ to the concentration of $10 \mathrm{mg} / \mathrm{mL}$ by keeping in a water bath at $37^{\circ} \mathrm{C}$ for $1 \mathrm{~h}$ and vortexing every $15 \mathrm{~min}$. Then, the medium was added to adjust the concentration for the experiments. Cells were treated with 0 , $0.25,0.5,1.0,1.5$, or $2.0 \mathrm{mg} / \mathrm{mL}$ MEL with or without addition of $0.2 \mu \mathrm{g} / \mathrm{mL}$ LPS (from Escherichia coli, serotype O26:B6; Sigma-Aldrich). Treatments were performed in duplicate for the cells of each cow.

Experiment 2: PAMP-Induced Specific Immune Responses of $M E C$ to $M E L$. For this experiment, MEL was dissolved in a manner similar to that 
in experiment 1 . The treatments consisted of a negative control (Neg; medium only), MEL control (1.5 mg/ $\mathrm{mL}$ MEL only), LPS control $(0.2 \mu \mathrm{g} / \mathrm{mL}$ LPS), LPS $+\operatorname{MEL}(0.2 \mu \mathrm{g} / \mathrm{mL} \operatorname{LPS}+1.5 \mathrm{mg} / \mathrm{mL}$ MEL $)$, LTA control $(20 \mu \mathrm{g} / \mathrm{mL}$ LTA from Staphylococcus aureus; Sigma-Aldrich), and LTA + MEL $(20 \mu \mathrm{g} / \mathrm{mL}$ LTA + $1.5 \mathrm{mg} / \mathrm{mL}$ MEL). The dose of MEL for this experiment was selected based on the results from experiment 1. All treatments were performed in duplicate for the cells of each cow.

\section{Total RNA Extraction and Quantitative Real-Time PCR}

Cells were harvested with $0.5 \mathrm{~mL}$ peqGold Trifast (Peqlab Biotechnologie GmbH, Erlangen, Germany) at $3 \mathrm{~h}$ postchallenge in the dose-response experiment and at 3,6 , and $24 \mathrm{~h}$ postchallenge in the pathogen-specific experiment. The RNA extraction was performed using Direct-zol RNA MiniPrep (Zymo Research Corp., Irvine, CA) following the instructions of the manufacturer. In brief, samples containing Trifast were mixed with the same amount of $99 \%$ alcohol, transferred to an RNA-free column, centrifuged, and washed with RNA wash buffer before adding DNase. After incubation for 15 min at room temperature, the column was washed twice with prewash solution, washed once more with wash buffer, and eluted with $15 \mu \mathrm{L}$ of RNA-free water.

Total RNA concentrations and purity were determined in $2 \mu \mathrm{L}$ of sample using a NanoDrop 2000 spectrophotometer (Thermo Fisher Scientific Inc., Waltham, MA) with an absorbance at 260 and $280 \mathrm{~nm}$. For the cDNA, $750 \mathrm{ng}$ of total RNA was reverse transcribed using 200 units of Moloney Murine Leukemia Virus Reverse Transcriptase (Promega Corp., Madison, WI) and 100 pmol of random hexamer (Invitrogen, Leek, the Netherlands).

The analyses of quantitative real-time PCR were done using a SensiMix SYBR Hi-ROX kit (Quantace, Biolabo, Chatel St. Denis, Switzerland) with a RotorGene 6000 (Corbett Research, Sydney, Australia). For the normalization of the quantitative real-time PCR results, the arithmetic means of 2 reference genes (GAPDH and $U B Q$ ) already known to be suitable for bovine MEC (Griesbeck-Zilch et al., 2008, 2009) were selected. Primers for reference and target genes were commercially synthesized (Microsynth, Balgach, Switzerland). The sequences are shown in Table 1. Cycle threshold values were calculated with Rotor Gene software version 1.7.75 (Corbett Research). The $\Delta \mathrm{Ct}$ of target genes was normalized according to the equation $\Delta \mathrm{Ct}=[\mathrm{Ct}$ (gene of interest) $-\mathrm{Ct}$ (mean of housekeeping genes $) \times-1]+20$.

\section{ELISA Assay}

Concentrations of $\mathrm{PGE}_{2}$ were measured in the supernatant of cells from experiment 1 at $3 \mathrm{~h}$ and from experiment 2 at $24 \mathrm{~h}$ postchallenge using a commercial ELISA kit (ADI-900-001; Enzo Life Sciences, Lausen, Switzerland) according to the manufacturer's protocol. The absorbance was measured using a Synergy Mx microplate reader (BioTek Instruments, Winooski, VT). The inter- and intra-assay coefficients of variation were 10.2 and $4.5 \%$, respectively.

\section{Viability Assay}

The MEC from the 4 cows were grown separately in 96 -well plates $\left(10 \times 10^{3}\right.$ cells/well $)$, and the same treatments described in experiments 1 and 2 were performed in duplicate for 3,6 , and $24 \mathrm{~h}$. After the incubation period, cells were washed 3 times with $100 \mu \mathrm{L}$ of sterile double-distilled water. Each well was filled with $100 \mu \mathrm{L}$ of DMEM/F12 medium with 3\% FBS, 1\% Pen-Strep, and $1 \%$ ITS and $20 \mu \mathrm{L}$ of CellTiter 96 AQueous One Solution (Promega, Dübendorf, Switzerland). The absorbance was measured $1 \mathrm{~h}$ after incubation at $490 \mathrm{~nm}$ using a Synergy Mx microplate reader (BioTek Instruments). The measurements are presented as a percentage, where Neg treatments are the reference (100\%).

\section{Statistical Analyses}

All data analyses were performed using SAS (version 9.4; SAS Institute Inc., Cary, NC) with cow as the experimental unit. Means of relative mRNA expression $(\Delta \mathrm{Ct})$ of target genes of duplicate treatments were calculated and used for the analyses. A repeatedmeasurement mixed-model analysis using the MIXED procedure was performed to examine the effects of MEL on the mRNA abundance of various factors and on supernatant $\mathrm{PGE}_{2}$ concentrations. For experiment 1 , the model included treatment as a fixed effect. For experiment 2 , the data were separated by hour $(3,6$, or $24 \mathrm{~h}$ postchallenge), and the model included treatment as a fixed effect. Cow was the specific term for the repeated statement. A compound structure was used. The PDIFF option was used to separate least squares means with adjustment for Tukey-Kramer. Significance was declared at $P<0.05$, and data are reported as means \pm standard errors of the mean.

\section{RESULTS}

Results of mRNA abundance of immune factors in MEC are presented in Tables 2 and 3. 
Table 1. Primer sequences for PCR ( $\mathrm{F}=$ forward, $\mathrm{R}=$ reverse), GenBank accession number, annealing temperature, and size

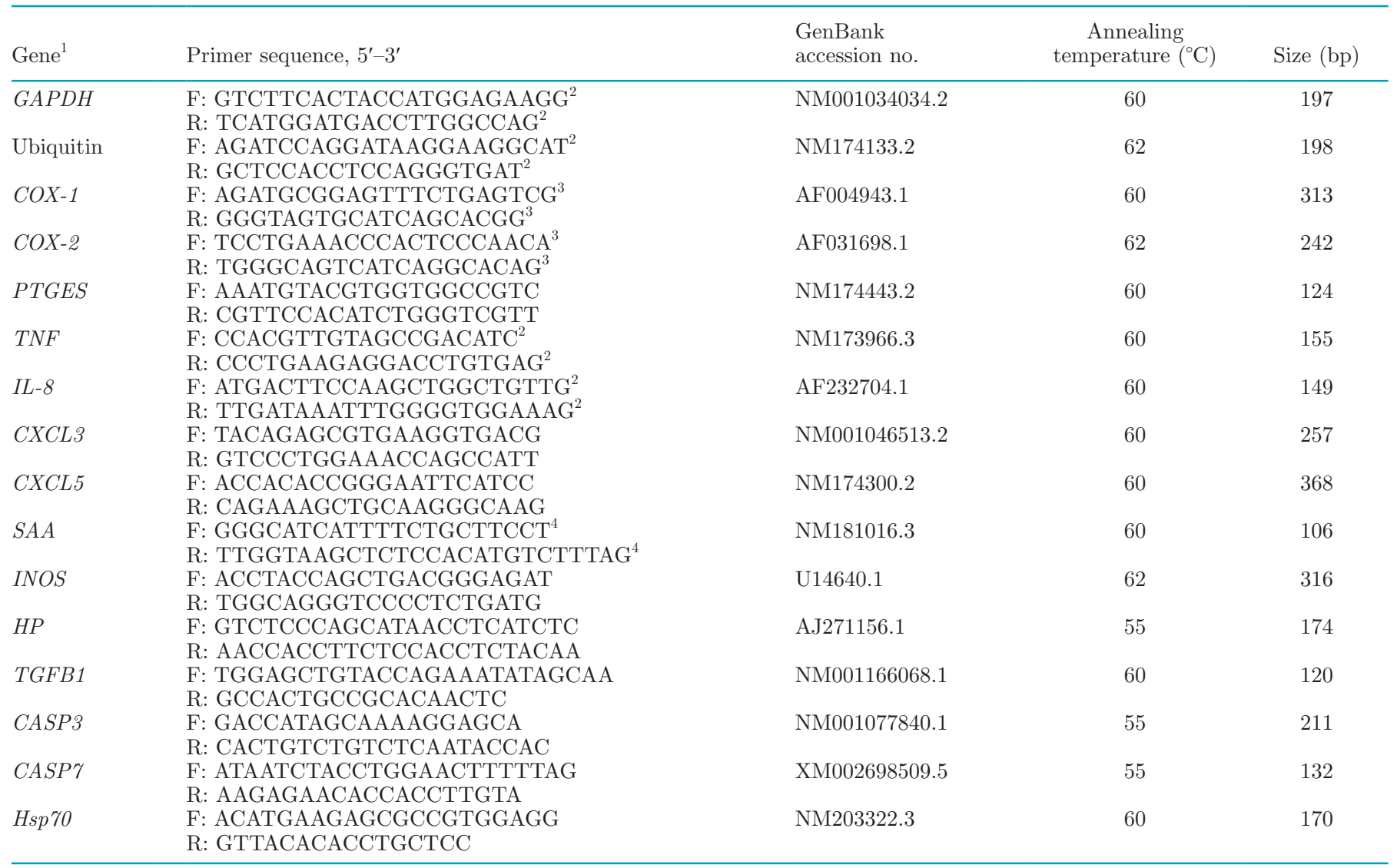

${ }^{1} C O X=$ cyclooxygenase $P T G E S=$ prostaglandin E synthase; $T N F=$ tumor necrosis factor; $C X C L=$ CXC chemokine ligand; $S A A=$ serum amyloid A; INOS = inducible nitric oxide synthase; $H P=$ haptoglobin; TGFB1 = transforming growth factor $\beta 1 ; C A S P=$ caspase; Hsp $70=$ heat shock protein family A.

${ }^{2}$ Griesbeck-Zilch et al. (2008).

${ }^{3}$ Pfaffl et al. (2003).

${ }^{4}$ Mukesh et al. (2010).

\section{Experiment 1: Immune Responses of MEC to Different Doses of MEL}

Total RNA yield and cell viability after $3 \mathrm{~h}$ of treatment were not different (data not shown). The mRNA abundance of COX-1 did not differ between treatments $(P>0.05)$. The mRNA abundance of COX-2 and of prostaglandin E synthase (PTGES) was upregulated $(P<0.05)$ in cells that were challenged with LPS and the addition of $0,0.25$, and $0.5 \mathrm{mg} / \mathrm{mL}$ MEL compared with the Neg control (no LPS). However, with doses of MEL of $1.0 \mathrm{mg} / \mathrm{mL}$ and greater, the mRNA abundance of COX-2 and PTGES was similar to that of the Neg control $(P=0.980$; Table 2$)$.

When LPS was added to the medium, TNF mRNA abundance increased $(P<0.0001)$ at $0,0.25,0.5$, and $1.0 \mathrm{mg} / \mathrm{mL}$ MEL, whereas at 1.5 and $2.0 \mathrm{mg} / \mathrm{mL}$ MEL the mRNA abundance was comparable $(P>0.05)$ with the level of non-challenged cells (Neg control; Figure $1 \mathrm{~A})$. Similar results were found in the mRNA abundance of IL-8 (Figure 1B) and the chemokines CXCL3 and CXCL5 (Table 2). The SAA and INOS mRNA abundance was greater with LPS challenge with $0,0.25$, and $0.5 \mathrm{mg} / \mathrm{mL}$ MEL but not with higher MEL concentrations. The mRNA abundance of the other measured factors was not significantly influenced by the different treatments except that the mRNA abundance of CASP3 was greater with LPS challenge compared with the control with the addition of $0.25 \mathrm{mg} / \mathrm{mL}$ MEL (Table 2).

The $\mathrm{PGE}_{2}$ concentrations measured in MEC supernatants were not significantly different between the Neg control and LPS with addition of any MEL concentrations $(P>0.05$; Figure $2 \mathrm{~A})$. However, in the Neg control, when MEL was added to the concentrations of 0.25 and $0.5 \mathrm{mg} / \mathrm{mL}, \mathrm{PGE}_{2}$ concentrations were 1.5 -fold 
greater $(P<0.05)$ and 2.5 -fold greater, respectively, compared with no addition of MEL $(0 \mathrm{mg} / \mathrm{mL})$. Based on these results, $1.5 \mathrm{mg} / \mathrm{mL}$ MEL was selected as the dose for experiment 2 .

\section{Experiment 2: PAMP-Induced Specific Immune Responses of MEC to MEL}

Total RNA yield was reduced $(P<0.05)$ at 3 and 24 $\mathrm{h}$ when MEL was added to the cells (Figure 3). Similarly, the cell viability was decreased $(P<0.05)$ at all time points once MEL was included in the treatments (Figure 3).

The mRNA abundance of COX-1 was not different between any treatment and time point $(P>0.05$; Table 3 ), whereas mRNA abundance of COX-2 was increased at $3 \mathrm{~h}(P=0.004)$ with LPS challenge. The mRNA abundance of PTGES was increased in LPS-challenged cells at $6 \mathrm{~h}(P=0.021)$ compared with Neg control, whereas the addition of MEL to the cells that received LPS inhibited this increase $(P<0.05$; Table 3$)$.

Furthermore, the mRNA abundance of TNF was increased $(P<0.01)$ by LPS compared with Neg at 6 and $24 \mathrm{~h}$ (Figure 4). When $1.5 \mathrm{mg} / \mathrm{mL}$ MEL was added to immune-activated cells (MEL + LPS and MEL + LTA), the mRNA abundance of TNF was similar to Neg and MEL controls $(P=0.400)$ in all time points (Figure 4). In the same manner, IL- 8 mRNA was upregulated in LPS and LTA at $6 \mathrm{~h}$ compared with both controls and at 3 and $24 \mathrm{~h}$ only when compared with the MEL control (Figure 5). Addition of MEL to PAMP treatments significantly downregulated IL-8 mRNA at 3, 6, and $24 \mathrm{~h}$ to the level of the Neg and MEL controls ( $P$ $<0.05$; Figure 5)

The chemokines CXCL3 and CXCL5 showed an increase in mRNA abundance in cells after challenge with LPS at 3, 6, and $24 \mathrm{~h}$ compared with the Neg and MEL controls $(P<0.05$; Table 3; Figure 5$)$. However, when challenged with LTA, CXCL3 showed no upregulation compared with the Neg control, whereas CXCL5 followed a similar pattern to the stimulation with LPS. With the addition of MEL to the immune-activated cells, CXCL3 decreased its abundance at $3 \mathrm{~h}(P<0.05$; Table 3), whereas in CXCL5 this happened predominantly in the later hours (6 and 24 h; Figure 5).

Inducible nitric oxide synthase (INOS; Table 3) and SAA (Figure 4) mRNA abundance increased when LPS was added to MEC at 3 and $6 \mathrm{~h}(P<0.05)$ and at 6 $\mathrm{h}$ with the LTA challenge $(P=0.041)$ compared with the Neg and MEL controls. Following similar patterns,

Table 2. Abundance of mRNA ( $\Delta$ threshold cycle; mean \pm SEM) in bovine mammary epithelial cells challenged with or without LPS from Escherichia coli and addition of different doses of meloxicam at $3 \mathrm{~h}$ postchallenge

\begin{tabular}{|c|c|c|c|c|c|c|c|}
\hline Factor $^{1}$ & Stimulation & \multicolumn{6}{|c|}{ Meloxicam $(\mathrm{mg} / \mathrm{mL})$} \\
\hline$C O X-1$ & LPS & $11.64 \pm 0.66$ & $11.82 \pm 0.72$ & $12.12 \pm 0.56$ & $12.11 \pm 0.68$ & $11.81 \pm 0.58$ & $11.84 \pm 0.56$ \\
\hline \multirow[t]{2}{*}{$C O X-2$} & Neg & $12.41 \pm 0.34$ & $13.56 \pm 0.59$ & $13.20 \pm 0.34$ & $12.45 \pm 0.36$ & $11.77 \pm 0.37$ & $11.81 \pm 0.51$ \\
\hline & LPS & $15.71 \pm 0.25^{\mathrm{a}}$ & $15.62 \pm 0.57^{\mathrm{a}}$ & $14.75 \pm 0.53^{\mathrm{a}}$ & $12.92 \pm 0.47$ & $12.06 \pm 0.29$ & $11.79 \pm 0.53$ \\
\hline PTGES & $\mathrm{Neg}$ & $14.02 \pm 0.24$ & $13.77 \pm 0.15$ & $13.59 \pm 0.26$ & $13.71 \pm 0.33$ & $13.57 \pm 0.20$ & $13.68 \pm 0.41$ \\
\hline CXCL3 & LPS & $19.76 \pm 0.08^{\mathrm{a}}$ & $21.32 \pm 0.40^{\mathrm{a}}$ & $20.87 \pm 0.46^{\mathrm{a}}$ & $18.38 \pm 0.55^{\mathrm{a}}$ & $14.05 \pm 0.26$ & $13.63 \pm 0.33$ \\
\hline \multirow{2}{*}{$C X C L 5$} & Neg & $12.86 \pm 0.91$ & $12.14 \pm 0.63$ & $10.91 \pm 1.06$ & $10.90 \pm 0.80$ & $11.13 \pm 0.72$ & $11.86 \pm 0.68$ \\
\hline & LPS & $18.81 \pm 0.55^{\mathrm{a}}$ & $17.91 \pm 0.53^{\mathrm{a}}$ & $15.84 \pm 0.65^{\mathrm{a}}$ & $13.16 \pm 0.55^{\mathrm{a}}$ & $11.39 \pm 0.72$ & $11.40 \pm 0.62$ \\
\hline \multirow[t]{2}{*}{$S A A$} & Neg & $8.66 \pm 0.75$ & $8.47 \pm 0.47$ & $8.10 \pm 0.67$ & $8.44 \pm 0.59$ & $7.66 \pm 0.88$ & $8.65 \pm 0.99$ \\
\hline & LPS & $18.57 \pm 0.30^{\mathrm{a}}$ & $13.93 \pm 0.43^{\mathrm{a}}$ & $11.25 \pm 0.37^{\mathrm{a}}$ & $9.05 \pm 0.31$ & $8.33 \pm 0.35$ & $8.39 \pm 0.68$ \\
\hline \multirow[t]{2}{*}{ INOS } & $\mathrm{Neg}$ & $7.17 \pm 0.47$ & $8.29 \pm 0.44$ & $6.07 \pm 0.75$ & $5.96 \pm 0.45$ & $4.65 \pm 0.58$ & $5.24 \pm 0.39$ \\
\hline & LPS & $13.79 \pm 0.20^{\mathrm{a}}$ & $11.08 \pm 0.72^{\mathrm{a}}$ & $8.62 \pm 0.30^{\mathrm{a}}$ & $5.92 \pm 0.31$ & $4.91 \pm 0.61$ & $4.90 \pm 0.31$ \\
\hline CASP3 & LPS & $17.19 \pm 0.22$ & $17.58 \pm 0.35^{\mathrm{a}}$ & $17.16 \pm 0.38$ & $16.83 \pm 0.32$ & $16.50 \pm 0.22$ & $16.68 \pm 0.12$ \\
\hline \multirow[t]{2}{*}{$C A S P 7$} & Neg & $11.76 \pm 0.71$ & $11.44 \pm 0.21$ & $11.46 \pm 0.79$ & $11.01 \pm 1.18$ & $12.43 \pm 1.00$ & $12.52 \pm 1.57$ \\
\hline & LPS & $12.58 \pm 0.92$ & $13.42 \pm 0.93$ & $12.41 \pm 0.98$ & $12.30 \pm 0.89$ & $11.37 \pm 0.79$ & $11.27 \pm 1.17$ \\
\hline \multirow{2}{*}{ Hsp 70} & Neg & $14.00 \pm 0.48$ & $13.87 \pm 0.42$ & $14.78 \pm 0.32$ & $17.53 \pm 0.76$ & $16.15 \pm 0.37$ & $15.21 \pm 0.41$ \\
\hline & LPS & $12.79 \pm 0.61$ & $14.01 \pm 0.37$ & $14.46 \pm 0.45$ & $17.32 \pm 0.71$ & $16.09 \pm 0.50$ & $14.50 \pm 0.95$ \\
\hline
\end{tabular}

${ }^{a}$ Means within time point and meloxicam dosage are significantly different $(P<0.05)$ between the negative control (Neg) and LPS treatment. ${ }^{1} C O X=$ cyclooxygenase; PTGES $=$ prostaglandin E synthase; $C X C L=\mathrm{CXC}$ chemokine ligand; $S A A=$ serum amyloid A; INOS = inducible nitric oxide synthase; $H P=$ haptoglobin; $T G F B 1=$ transforming growth factor $\beta 1 ; C A S P=$ caspase; $H s p 70=$ heat shock protein. 
MEL diminished $(P<0.05)$ the increase of SAA and INOS mRNA abundance when the NSAID was added to LPS at all time points and LTA at 6 and $24 \mathrm{~h}$.

Haptoglobin, transforming growth factor $\beta 1$, and caspase 3 and 7 mRNA abundance did not differ at any time point between any treatment $(P>0.05)$. However, heat shock protein 70 (Hsp70) mRNA expressions were significantly upregulated $(P<0.05$; Table 3 ) with the addition of MEL. The $\mathrm{PGE}_{2}$ concentrations measured in the cell supernatants at $24 \mathrm{~h}$ postchallenge were significantly reduced $(P<0.05$; Figure $2 \mathrm{~B})$ by MEL treatment.

\section{DISCUSSION}

Systemic administration of MEL, a COX-2 preferential NSAID, is established as a supportive therapy to antibiotic treatments for mastitis in dairy cows (McDougall et al., 2009); however, its specific effects on the mammary gland immune system are unknown.
Primary mammary epithelial cells in culture were shown to mirror the mammary immune response to different pathogens by expression of different immune factors (Wellnitz and Kerr, 2004; Griesbeck-Zilch et al., 2008; Dan et al., 2018). Cells of 4 cows cultured separately were used to provide the biological repeatability. Three times of challenge were performed $(3,6$, and 24 h) to capture changes in mRNA expression of factors that are usually induced at different time points in the course of inflammation (Griesbeck-Zilch et al., 2008). To test dose effects, MEL was added to bovine MEC at increasing concentrations with or without additional challenge with PAMP. The treatment with LPS from $E$. coli induced an expected immune response in the cells and increased the mRNA abundance of COX-2, PTGES, TNF, IL-8, SAA, INOS, CXCL3, and CXCL5. The increase of mRNA abundance of mentioned immune factors by LPS was prevented when 1.5 and 2.0 $\mathrm{mg} / \mathrm{mL}$ MEL were added to those immune-stimulated cells but not with lower doses of MEL. The results from

Table 3. Abundance of mRNA ( $\Delta$ threshold cycle; mean \pm SEM) in bovine mammary epithelial cells challenged with LPS from Escherichia coli or lipoteichoic acid (LTA) from Staphylococcus aureus with or without the addition of $1.5 \mathrm{mg} / \mathrm{mL}$ meloxicam (MEL)

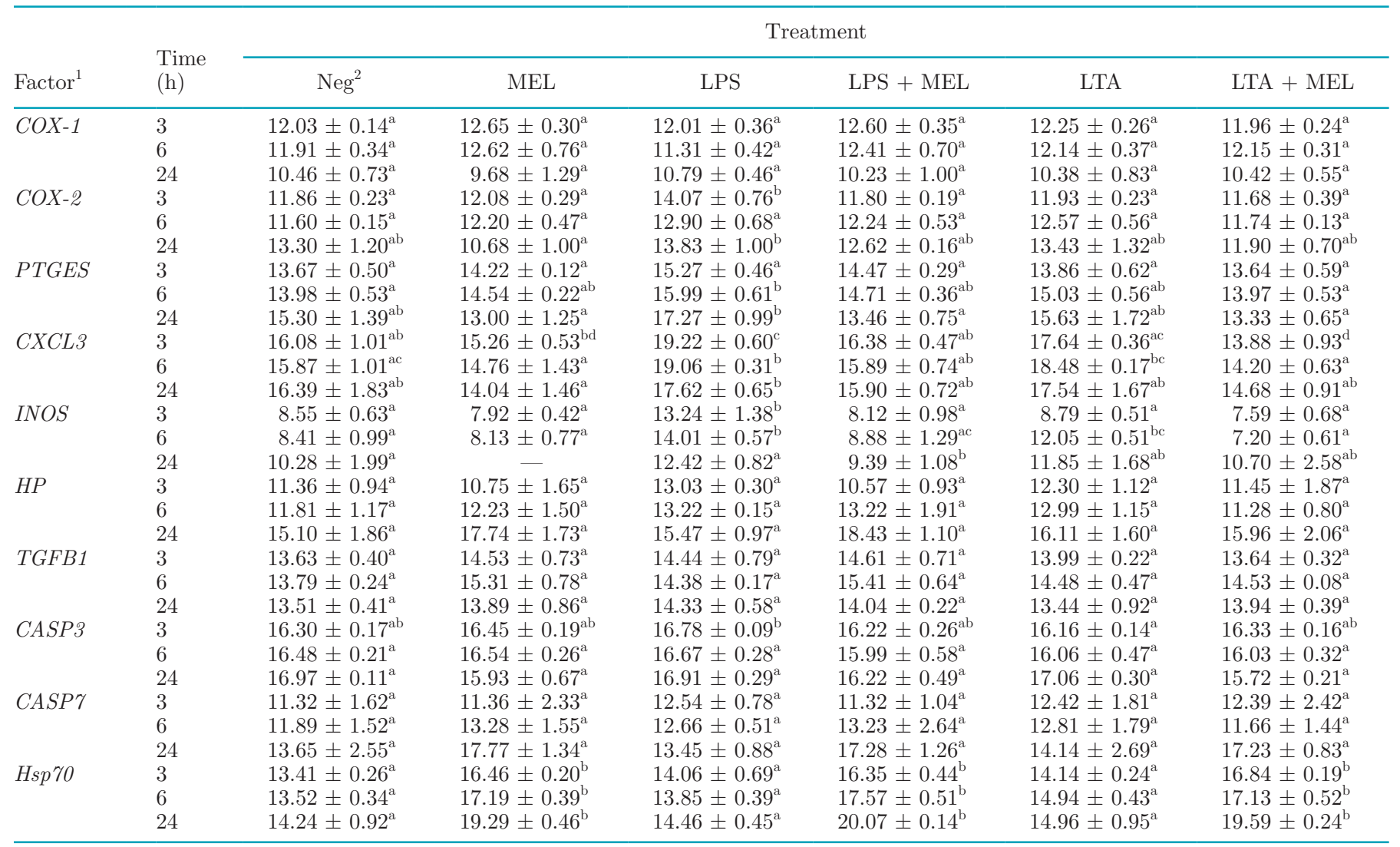

\footnotetext{
${ }^{\mathrm{a}-\mathrm{d}}$ Means with different superscripts within factor and time point are significantly different $(P<0.05)$ between treatments.

${ }^{1} C O X=$ cyclooxygenase; $P T G E S=$ prostaglandin E synthase; $C X C L=\mathrm{CXC}$ chemokine ligand; $I N O S=$ inducible nitric oxide synthase; $H P=$ haptoglobin; TGFB1 = transforming growth factor $\beta 1$; CASP = caspase; $H s p 70=$ heat shock protein.

${ }^{2}$ Negative control.
} 

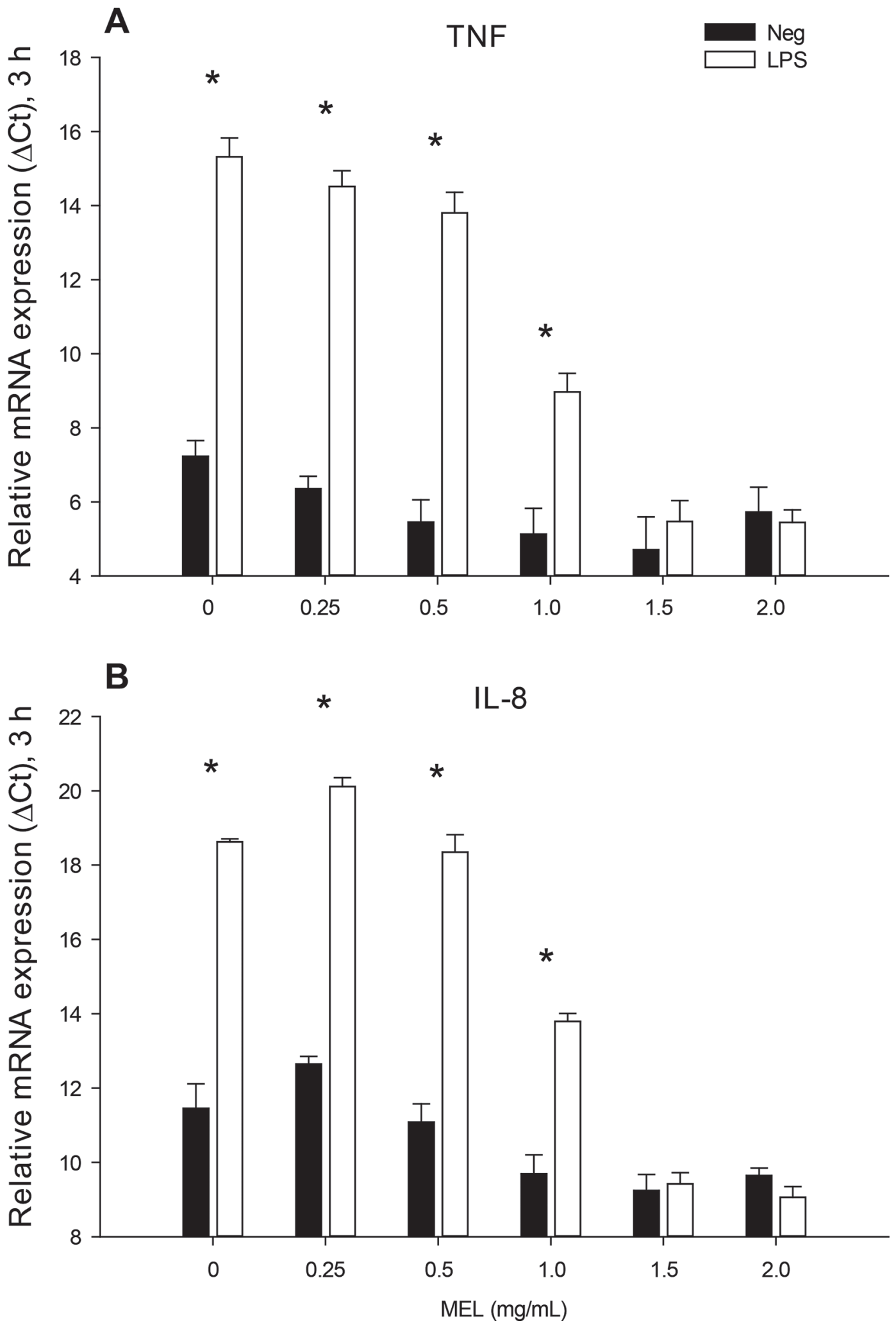

Figure 1. Relative mRNA abundance $[\Delta$ threshold cycle $(\mathrm{Ct})$; mean $\pm \mathrm{SEM}]$ in primary bovine epithelial mammary cells of (A) tumor necrosis factor (TNF) and (B) IL-8 at $3 \mathrm{~h}$ postchallenge of LPS from Escherichia coli. Treatments were 0, 0.25, 0.5, 1.0, 1.5, or 2.0 mg/mL of meloxicam (MEL) with $0.2 \mu \mathrm{g}$ of LPS (white bars) or without LPS (Neg; black bars). Asterisks represent differences $(P<0.05)$ between Neg and LPS within MEL concentrations. 

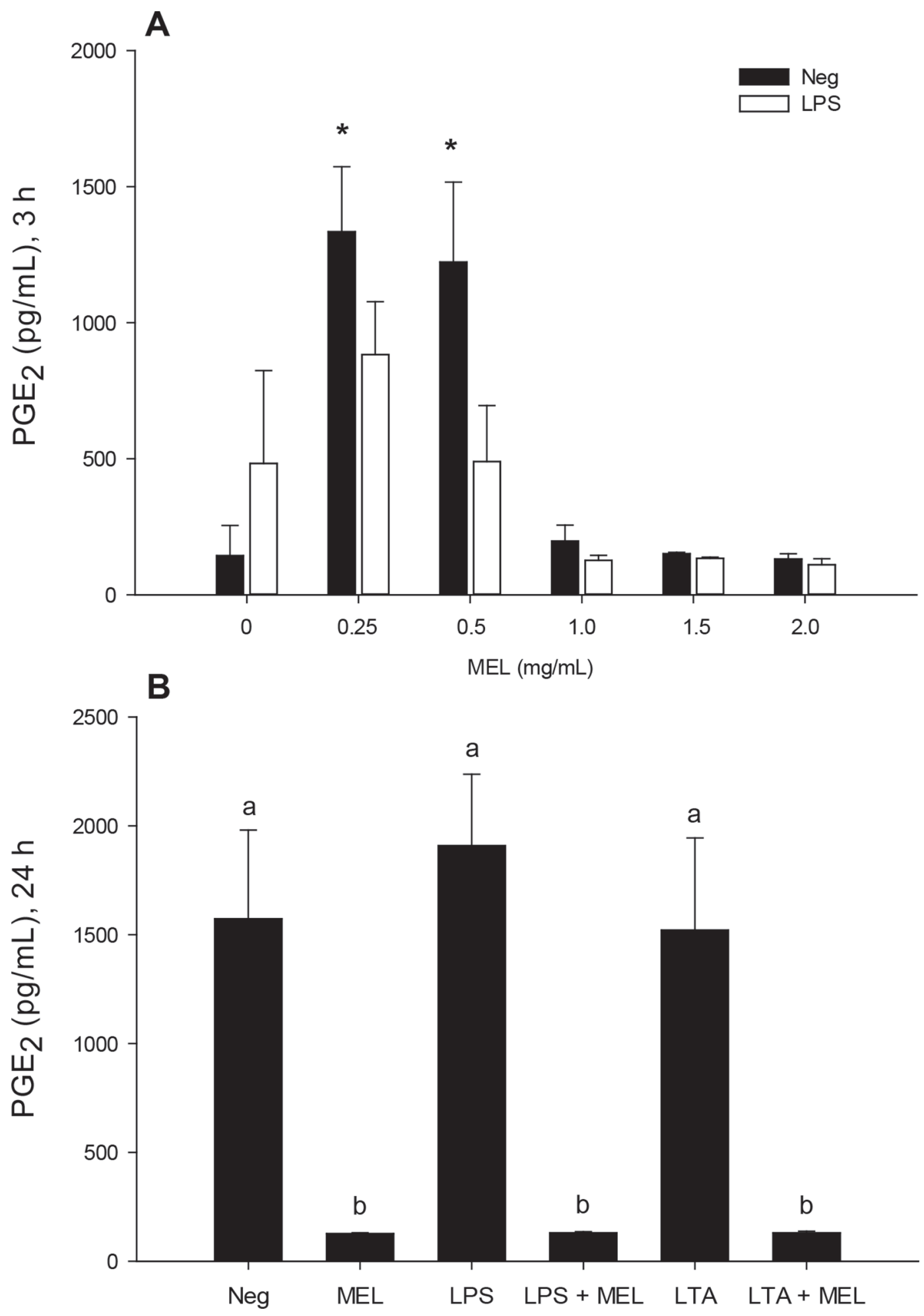

Figure 2. Prostaglandin $(\mathrm{PG}) \mathrm{E}_{2}$ concentrations $(\mathrm{pg} / \mathrm{mL}$; mean $\pm \mathrm{SEM}$ ) measured in the supernatant of bovine mammary epithelial cells at (A) $3 \mathrm{~h}$ and (B) $24 \mathrm{~h}$ postchallenge. (A) Treatments were $0,0.25,0.5,1.0,1.5$, or $2.0 \mathrm{mg} / \mathrm{mL}$ of meloxicam (MEL) with $0.2 \mu \mathrm{g}$ of LPS (white bars) or without LPS (Neg; black bars). Asterisk represents difference $(P<0.05)$ compared with Neg control with $0 \mathrm{mg} / \mathrm{mL}$ of MEL. (B) Treatments were negative control (Neg; medium only), MEL $(1.5 \mathrm{mg} / \mathrm{mL})$, LPS $(0.2 \mu \mathrm{g} / \mathrm{mL})$, LPS + MEL, lipoteichoic acid (LTA; $20 \mu \mathrm{g} / \mathrm{mL})$, and LTA + MEL. Different letters $(\mathrm{a}, \mathrm{b})$ represent differences between treatments $(P<0.05)$. 
experiment 1 showed that MEL had a strong effect on the immune response of mammary epithelial cells in a dose-dependent manner. Due to the findings of this experiment, $1.5 \mathrm{mg} / \mathrm{mL}$ was selected as a suitable dose to investigate MEL effects on the immune response of MEC to different pathogens.

As E. coli (gram-negative) and Staph. aureus (grampositive) are frequent inducers of acute and chronic
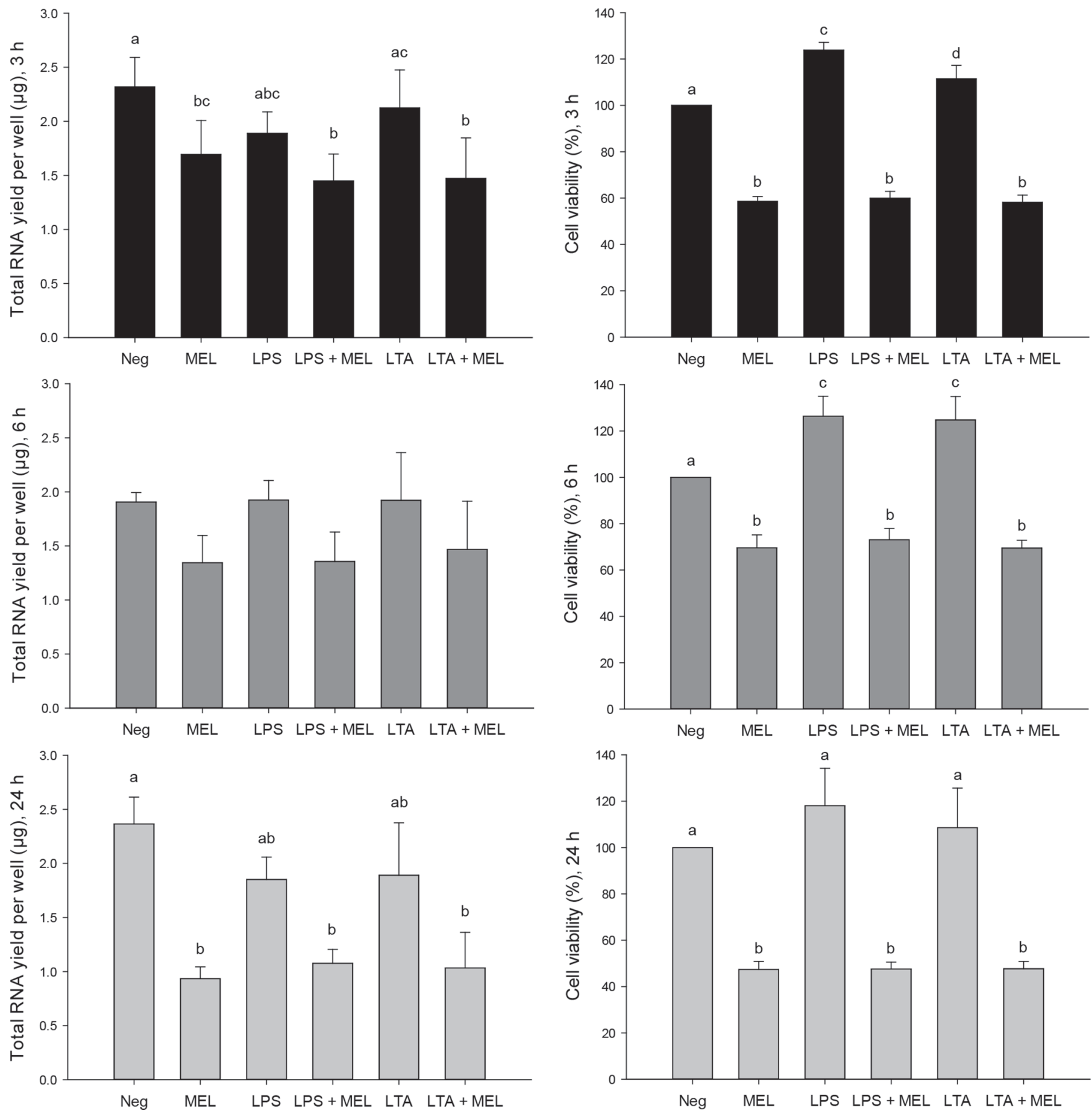

Figure 3. Primary bovine epithelial mammary cells total RNA yield ( $\mu \mathrm{g})$ per well and cell viability (\%; mean \pm SEM) at 3, 6, and 24 h postchallenge of LPS from Escherichia coli or lipoteichoic acid (LTA) from Staphylococcus aureus. Treatments were negative control (Neg; medium only), meloxicam (MEL; $1.5 \mathrm{mg} / \mathrm{mL})$, LPS $(0.2 \mu \mathrm{g}$ of LPS), LPS + MEL, LTA (20 $\mu \mathrm{g}$ of LTA), and LTA + MEL. Different letters (a-d) represent significant treatment effects $(P<0.05)$. 
mastitis, respectively, LPS and LTA were the chosen PAMP to compare MEL effects during inflammation induced by different pathogens. The concentrations used were selected based on SCC increase in the mammary gland of previous studies in vivo, which showed that $20 \mu \mathrm{g} / \mathrm{mL}$ LTA produced similar inflammatory
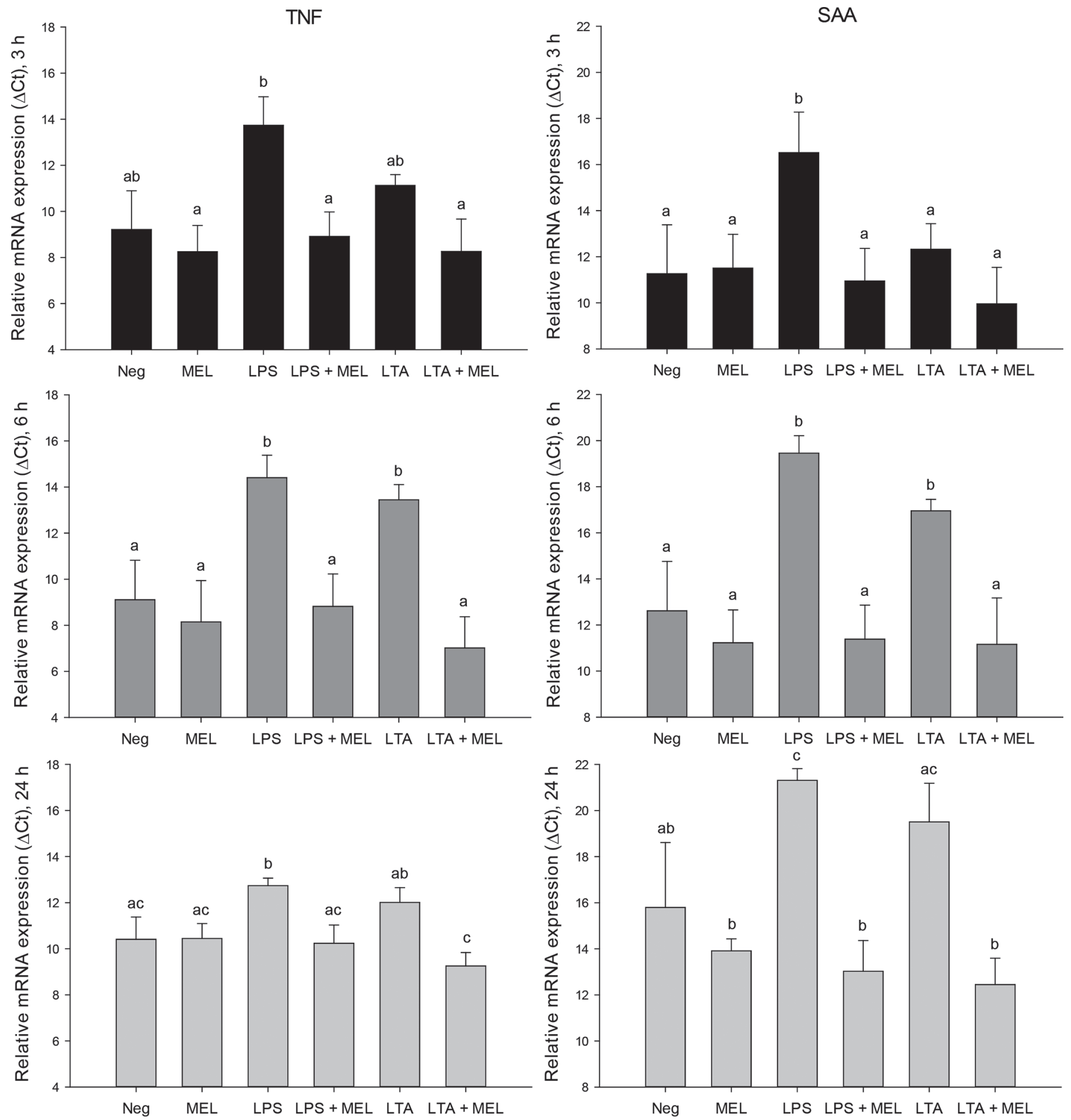

Figure 4. Relative mRNA abundance $[\Delta$ threshold cycle $(\mathrm{Ct})$; mean $\pm \mathrm{SEM}]$ in primary bovine epithelial mammary cells of tumor necrosis factor (TNF) and serum amyloid A (SAA) at 3, 6, and $24 \mathrm{~h}$ postchallenge of LPS from Escherichia coli or lipoteichoic acid (LTA) from Staphylococcus aureus. Treatments were negative control (Neg; medium only), meloxicam (MEL; $1.5 \mathrm{mg} / \mathrm{mL}), \mathrm{LPS}(0.2 \mu \mathrm{g}$ of LPS), LPS + MEL, LTA (20 $\mathrm{g}$ of LTA), and LTA + MEL. Different letters $(\mathrm{a}-\mathrm{c})$ represent significant treatment effects $(P<0.05)$. 
responses to $0.2 \mu \mathrm{g} / \mathrm{mL}$ LPS (Wellnitz et al., 2013, 2016). In the present study, the mRNA expression of proinflammatory cytokines and chemokines as well the $\mathrm{PGE}_{2}$ secretion showed minimal or no differences between PAMP stimulation (LPS and LTA).
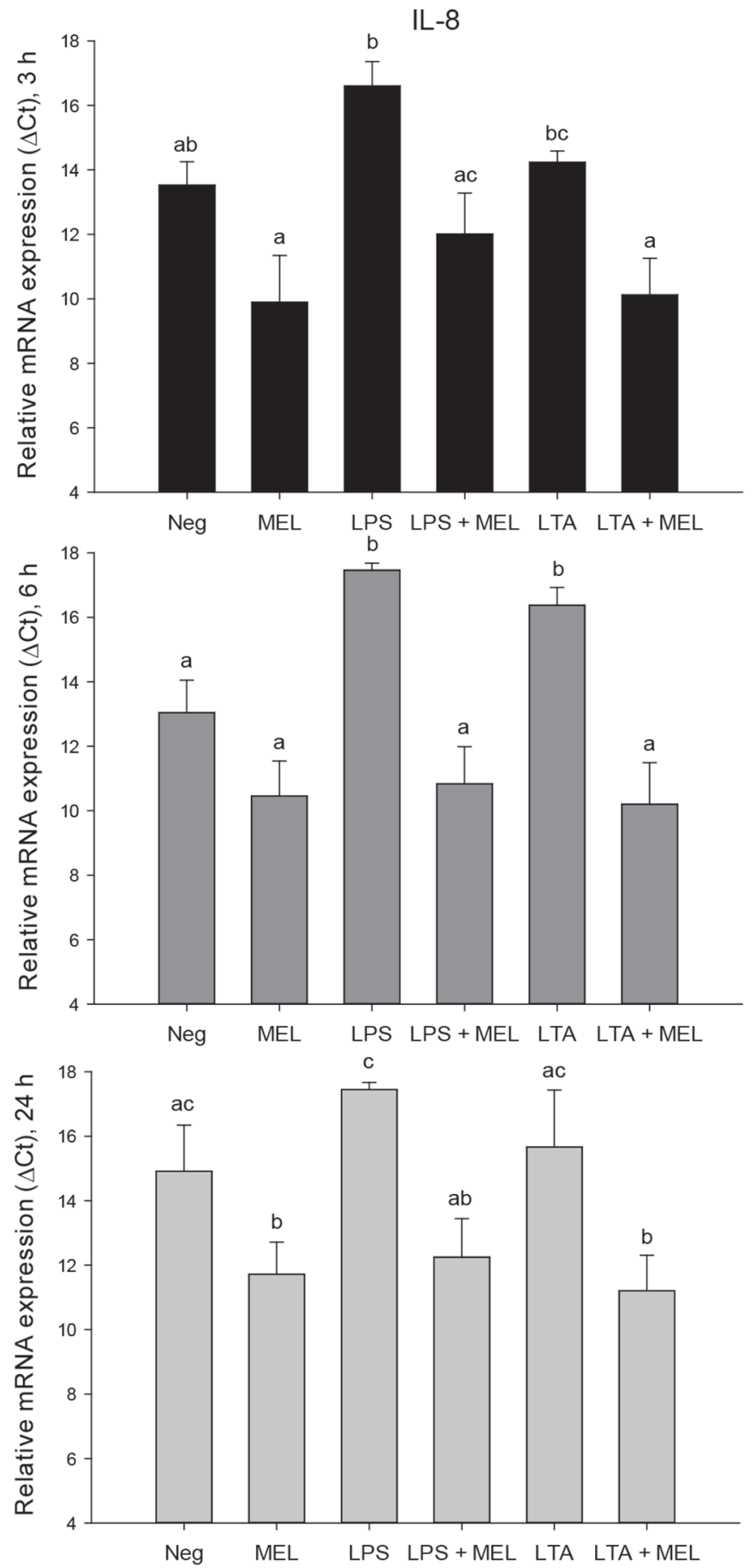

Cytokines and chemokines are important regulators of the mammary immune response, and their mRNA abundance in MEC is known to increase in response to immunostimulants (Griesbeck-Zilch et al., 2008). Therefore, the increase of mRNA abundance of TNF,
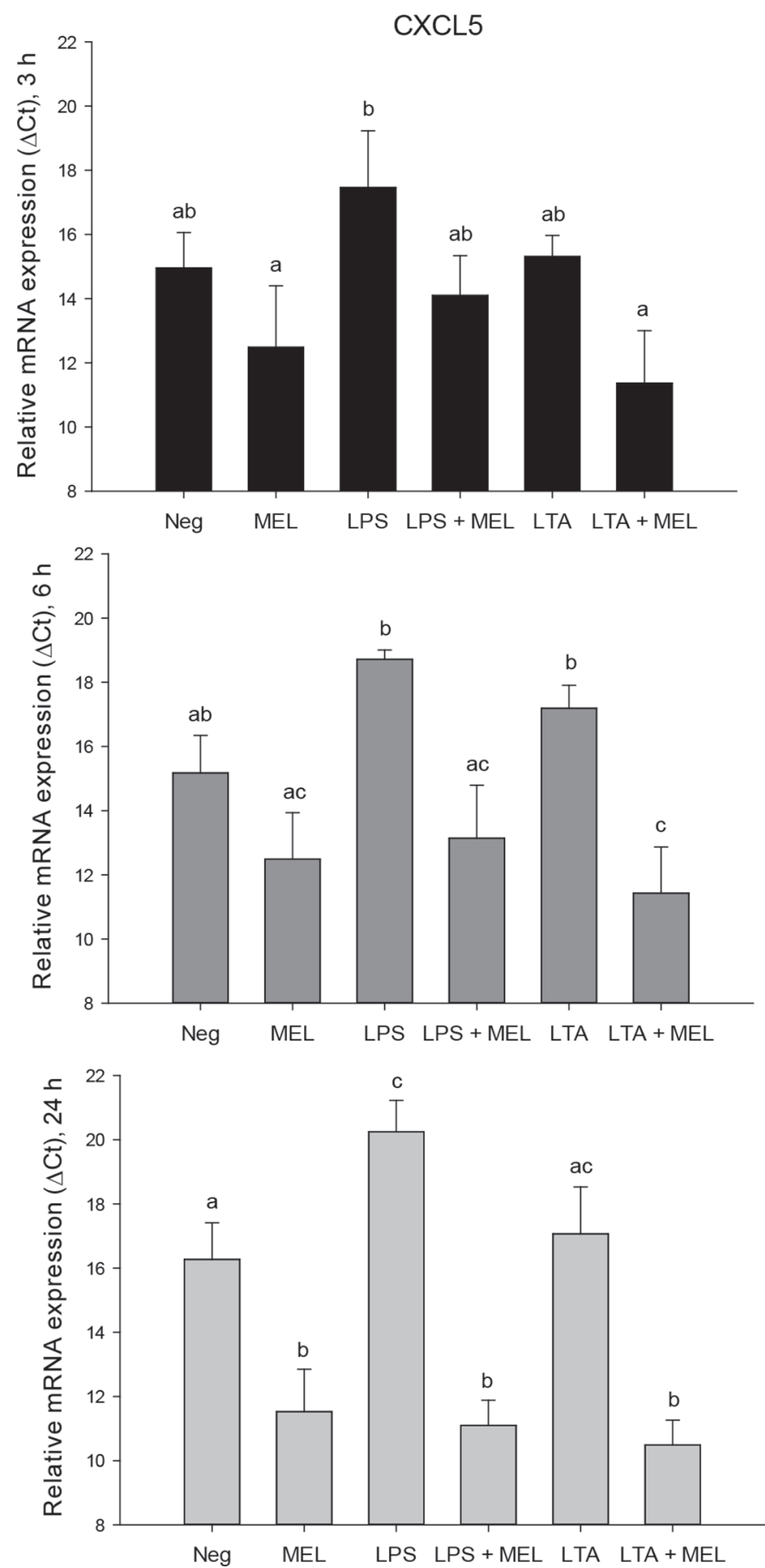

Figure 5. Relative mRNA abundance [ $\Delta$ threshold cycle (Ct); mean \pm SEM] in primary bovine epithelial mammary cells of IL-8 and CXC chemokine ligand 5 (CXCL5) at 3,6, and 24 h postchallenge of LPS from Escherichia coli or lipoteichoic acid (LTA) from Staphylococcus aureus. Treatments were negative control (Neg; medium only), meloxicam (MEL; $1.5 \mathrm{mg} / \mathrm{mL})$, LPS (0.2 $\mu \mathrm{g}$ of LPS), LPS + MEL, LTA (20 $\mu \mathrm{g}$ of LTA), and LTA + MEL. Different letters $(\mathrm{a}-\mathrm{c})$ represent significant treatment effects $(P<0.05)$. 
IL-8, CXCL5, and CXCL3 in response to LPS and LTA challenge was expected. When cells received 1.5 $\mathrm{mg} / \mathrm{mL}$ MEL in addition to the PAMP, the mRNA abundance of most cytokines was similar to nontreated controls at all time points. Even if more attenuate, Dan et al. (2018) found similar results in mRNA abundance of TNF and IL- 8 of MEC treated with $0.2 \mu \mathrm{g} / \mathrm{mL}$ LPS in combination with 1.25 or $2.5 \mathrm{mg} / \mathrm{mL}$ ketoprofen, a non-selective NSAID. In an inflamed mammary gland it could be interesting to decrease the exacerbated production of leukocyte chemoattractants by MEL because it is known that excessive neutrophil infiltration leads to production of reactive oxygen species, tissue destruction, and mortality (Kolaczkowska and Kubes, 2013). On the other hand, the role of leukocytes as first line responders is important, and maintenance of a certain level of neutrophil infiltration is essential for the phagocytosis and elimination of bacteria from the mammary gland to cure mastitis (Aitken et al., 2011). Therefore, chemoattractants are of importance for the mammary immune response, and Korkmaz et al. (2018) found that cows with greater production of milk IL-8 were more capable of limiting bacterial growth during mastitis than cows with lower milk IL-8.

Expression of INOS and SAA is highly induced during the acute phase of an inflammatory process such as mastitis. Our results showed a characteristic increase of INOS and SAA mRNA abundance to LPS, starting at $3 \mathrm{~h}$ and remaining up until $24 \mathrm{~h}$ after challenge. Among other functions, SAA stimulates leukocytes to secrete TNF, and it is involved in the recruitment of neutrophils to the site of inflammation (Badolato et al., 1994). Although SAA functions in inflammatory processes were well studied, Cheng et al. (2018) showed for the first time that SAA has a protective role against LPS-induced inflammation, binding to LPS and helping its clearance. Our results pointed to no significant differences in mRNA expression of SAA to Neg controls when MEL was added to immune-challenged cells. In light of these new results, one can only speculate that this prevention of SAA mRNA upregulation by LPS may have an effect on the recovery from gram-negative mastitis because the clearance of LPS from the mammary gland would be disturbed by reduced SAA.

Meloxicam, a more COX-2 selective NSAID, was designed to reduce the side effects, such as renal toxicity and gastrointestinal disorders, occasioned by the inhibition of COX-1 (Engelhardt et al., 1996a). Because COX-1 is constitutively expressed in most tissues, the mRNA abundance did not increase in any treatment in MEC. Interestingly, COX-2 mRNA abundance was increased in LPS treatment at $3 \mathrm{~h}$, and only later at $24 \mathrm{~h}$ compared with the negative control. Gilroy et al. (1999), using induced pleurisy in rats as a model to study inflammation, showed an upregulation of COX-2 protein expression in the first hours (2 h) after challenge, which coincided with the maximal $\mathrm{PGE}_{2}$ synthesis, but the second increase of COX-2 at $48 \mathrm{~h}$ was not accompanied by $\mathrm{PGE}_{2}$ production. The authors concluded that in the earlier phase of the immune response COX-2 may be proinflammatory; however, in the later phase COX-2 may help the resolution of inflammation through an alternative pathway. A more comprehensive study is needed to analyze whether this anti-inflammatory effect found by Gilroy et al. (1999) can be compared with the second increase of COX-2 at $24 \mathrm{~h}$ postchallenge in our study.

Prostaglandin E synthase, the enzyme that catalyzes the last step in the conversion of arachidonic acid to $\mathrm{PGE}_{2}$, had similar mRNA abundance to the Neg control at $24 \mathrm{~h}$ when MEL was added to immunestimulated MEC. A similar pattern was found in $\mathrm{PGE}_{2}$ concentrations measured in MEC supernatant. Results of the present study show that the addition of MEL to bovine MEC diminishes the processes of inflammation not only at the mRNA level but also at the protein level. In contrast to our results, Dan et al. (2018) did not find any change in the synthesis of $\mathrm{PGE}_{2}$ using similar doses (1.25 and $2.5 \mathrm{mg} / \mathrm{mL})$ of ketoprofen in addition to LPS-challenged MEC, letting us conclude that the selectivity and type of NSAID are essential for this response.

The viability of the cells and the total RNA yield were decreased in response to MEL. To the best of our knowledge, this is the first study reporting the detrimental effects of MEL on MEC of Holstein dairy cows, and although MEL likely impairs proliferation of the cells, caspase 3 and 7 as well as transforming growth factor $\beta 1$, known to be involved in many steps of apoptosis, were not altered in any treatment at any time point. Heat shock protein is widely acceptable as a major stress-inducible protein with cytoprotective functions (Hulina et al., 2018). Conversely, some authors defend that Hsp70 is part of normal immunoregulatory response, controlling proinflammatory responses during inflammation (van Eden et al., 1998; Pockley, 2003). Interestingly, Hsp70 mRNA abundance was increased when MEL was added to MEC. At the same time, the mRNA abundance of proinflammatory mediators remained similar to the Neg control once MEL was added to immune-stimulated cells, indicating effects of MEL on MEC besides the limitation of expression of immune factors during inflammation.

\section{CONCLUSIONS}

Meloxicam showed a clear interaction with the immune response of cells from the mammary gland of dairy 
cows challenged with LPS from E. coli or LTA from Staph. aureus, diminishing the mRNA abundance of key inflammatory mediators in a dose-dependent manner. Similarly, MEL inhibited synthesis of $\mathrm{PGE}_{2}$, one of the most relevant prostaglandins during the process of inflammation. This is the first study showing that MEL has the potential to affect the immune response of bovine MEC in vitro. These effects likely limit the inflammatory processes during mastitis. Furthermore, it was shown that MEL had detrimental effects on the viability of the mammary cells, which could indicate that MEL treatment may induce tissue damage in the mammary gland. Whether the character of these novel discoveries would support or impair the elimination of bacteria from the infected mammary gland during mastitis therapy with MEL still needs a comprehensive investigation.

\section{ACKNOWLEDGMENTS}

The authors thank Claudine Morel and Chantal Philipona (Veterinary Physiology, Vetsuisse Faculty, University of Bern, Switzerland) for their laboratory assistance.

\section{REFERENCES}

Aitken, S. L., C. M. Corl, and L. M. Sordillo. 2011. Immunopathology of mastitis: Insights into disease recognition and resolution. J. Mammary Gland Biol. Neoplasia 16:291-304. https://doi.org/10 .1007/s10911-011-9230-4.

Badolato, R., J. M. Wang, W. J. Murphy, A. R. Lloyd, D. F. Michiel, L. L. Bausserman, D. J. Kelvin, and J. J. Oppenheim. 1994. Serum amyloid A is a chemoattractant: Induction of migration, adhesion, and tissue infiltration of monocytes and polymorphonuclear leukocytes. J. Exp. Med. 180:203-209. https://doi.org/10.1084/jem .180.1.203.

Cheng, N., Y. Liang, X. Du, and R. D. Ye. 2018. Serum amyloid A promotes LPS clearance and suppresses LPS-induced inflammation and tissue injury. EMBO Rep. 19. https://doi.org/10.15252/ embr.201745517.

Dan, D., R. M. Bruckmaier, and O. Wellnitz. 2018. Ketoprofen affects the mammary immune response in dairy cows in vivo and in vitro. J. Dairy Sci. 101:11321-11329. https://doi.org/10.3168/jds .2018-15034.

Engelhardt, G., R. Bögel, C. Schnitzer, and R. Utzmann. 1996a. Meloxicam: Influence on arachidonic acid metabolism: Part 1. In vitro findings. Biochem. Pharmacol. 51:21-28. https://doi.org/10 .1016/0006-2952(95)02111-6.

Engelhardt, G., R. Bögel, C. Schnitzler, and R. Utzmann. 1996b. Meloxicam: Influence on arachidonic acid metabolism: Part 2. In vivo findings. Biochem. Pharmacol. 51:29-38. https://doi.org/10 .1016/0006-2952(95)02110-8.

Fitzpatrick, C. E., N. Chapinal, C. S. Petersson-Wolfe, T. J. DeVries, D. F. Kelton, T. F. Duffield, and K. E. Leslie. 2013. The effect of meloxicam on pain sensitivity, rumination time, and clinical signs in dairy cows with endotoxin-induced clinical mastitis. J. Dairy Sci. 96:2847-2856. https://doi.org/10.3168/jds.2012-5855.

Gilroy, D. W., P. R. Colville-Nash, D. Willis, J. Chivers, M. J. PaulClark, and D. A. Willoughby. 1999. Inducible cyclooxygenase may have anti-inflammatory properties. Nat. Med. 5:698-701. https:// doi.org/10.1038/9550.
Goossens, K., M. Van Poucke, A. Van Soom, J. Vandesompele, A. Van Zeveren, and L. J. Peelman. 2005. Selection of reference genes for quantitative real-time PCR in bovine preimplantation embryos. BMC Dev. Biol. 5:27. https://doi.org/10.1186/1471-213X-5-27.

Griesbeck-Zilch, B., H. H. D. Meyer, C. H. Kuhn, M. Schwerin, and O. Wellnitz. 2008. Staphylococcus aureus and Escherichia coli cause deviating expression profiles of cytokines and lactoferrin messenger ribonucleic acid in mammary epithelial cells. J. Dairy Sci. 91:2215-2224. https://doi.org/10.3168/jds.2007-0752.

Griesbeck-Zilch, B., M. Osman, C. Kühn, M. Schwerin, R. H. Bruckmaier, M. W. Pfaffl, A. Hammerle-Fickinger, H. H. D. Meyer, and O. Wellnitz. 2009. Analysis of key molecules of the innate immune system in mammary epithelial cells isolated from marker-assisted and conventionally selected cattle. J. Dairy Sci. 92:4621-4633. https://doi.org/10.3168/jds.2008-1954.

Holdsworth, S. R., and P.-Y. Gan. 2015. Cytokines: Names and numbers you should care about. Clin. J. Am. Soc. Nephrol. 10:22432254. https://doi.org/10.2215/CJN.07590714.

Hulina, A., M. Grdić Rajković, D. Jakšić Despot, D. Jelić, A. Dojder, I. Čepelak, and L. Rumora. 2018. Extracellular Hsp70 induces inflammation and modulates LPS/LTA-stimulated inflammatory response in THP-1 cells. Cell Stress Chaperones 23:373-384. https: //doi.org/10.1007/s12192-017-0847-0.

Kawahara, K., H. Hohjoh, T. Inazumi, S. Tsuchiya, and Y. Sugimoto. 2015. Prostaglandin E2-induced inflammation: Relevance of prostaglandin E receptors. Biochim. Biophys. Acta 1851:414-421. https://doi.org/10.1016/j.bbalip.2014.07.008.

Kolaczkowska, E., and P. Kubes. 2013. Neutrophil recruitment and function in health and inflammation. Nat. Rev. Immunol. 13:159 175. https://doi.org/10.1038/nri3399.

Korkmaz, F. T., T. H. Elsasser, and D. E. Kerr. 2018. Variation in fibroblast expression of toll-like receptor 4 and lipopolysaccharideinduced cytokine production between animals predicts control of bacterial growth but not severity of Escherichia coli mastitis. J. Dairy Sci. 101:10098-10115. https://doi.org/10.3168/jds.2017 -14372 .

Lawrence, T. 2009. The nuclear factor NF- $\kappa$ B pathway in inflammation. Cold Spring Harb. Perspect. Biol. 1:a001651. https://doi .org/10.1101/cshperspect.a001651.

McDougall, S., M. A. Bryan, and R. M. Tiddy. 2009. Effect of treatment with the nonsteroidal antiinflammatory meloxicam on milk production, somatic cell count, probability of re-treatment, and culling of dairy cows with mild clinical mastitis. J. Dairy Sci. 92:4421-4431. https://doi.org/10.3168/jds.2009-2284.

McDougall, S., E. Abbeloos, S. Piepers, A. S. Rao, S. Astiz, T. van Werven, J. Statham, and N. Pérez-Villalobos. 2016. Addition of meloxicam to the treatment of clinical mastitis improves subsequent reproductive performance. J. Dairy Sci. 99:2026-2042. https: //doi.org/10.3168/jds.2015-9615.

Mukesh, M., M. Bionaz, D. E. Graugnard, J. K. Drackley, and J. J. Loor. 2010. Adipose tissue depots of Holstein cows are immune responsive: Inflammatory gene expression in vitro. Domest. Anim. Endocrinol. 38:168-178. https://doi.org/10.1016/j.domaniend .2009.10.001.

Pfaffl, M. W., S. L. Wittmann, H. H. D. Meyer, and R. M. Bruckmaier. 2003. Gene expression of immunologically important factors in blood cells, milk cells, and mammary tissue of cows. J. Dairy Sci. 86:538-545. https://doi.org/10.3168/jds.S0022-0302(03)73632-7.

Pockley, A. G. 2003. Heat shock proteins as regulators of the immune response. Lancet 362:469-476. https://doi.org/10.1016/S0140 $-6736(03) 14075-5$.

Ricciotti, E., and G. A. FitzGerald. 2011. Prostaglandins and inflammation. Arterioscler. Thromb. Vasc. Biol. 31:986-1000. https:// doi.org/10.1161/ATVBAHA.110.207449.

Tang, D., R. Kang, C. B. Coyne, H. J. Zeh, and M. T. Lotze. 2012. PAMPs and DAMPs: Signal 0s that spur autophagy and immunity. Immunol. Rev. 249:158-175. https://doi.org/10.1111/j.1600 $-065 X .2012 .01146 . x$.

Tilley, S. L., T. M. Coffman, and B. H. Koller. 2001. Mixed messages: Modulation of inflammation and immune responses by prostaglan- 
dins and thromboxanes. J. Clin. Invest. 108:15-23. https://doi .org/10.1172/JCI13416.

Ushikubi, F., E. Segi, Y. Sugimoto, T. Murata, T. Matsuoka, T. Kobayashi, H. Hizaki, K. Tuboi, M. Katsuyama, A. Ichikawa, T. Tanaka, N. Yoshida, and S. Narumiya. 1998. Impaired febrile response in mice lacking the prostaglandin E receptor subtype EP3. Nature 395:281-284. https://doi.org/10.1038/26233.

van Eden, W., R. Van Der Zee, A. G. Paul, B. J. Prakken, U. Wendling, S. M. Anderton, and M. H. Wauben. 1998. Do heat shock proteins control the balance of T-cell regulation in inflammatory diseases? Immunol. Today 19:303-307. https://doi.org/10 .1016/S0167-5699(98)01283-3.

Wellnitz, O., E. T. Arnold, R. M. Bruckmaier, V. C. Farr, I. Politis, J. H. White, and B. Zavizion. 2011. Lipopolysaccharide and lipoteichoic acid induce different immune responses in the bovine mammary gland. J. Dairy Sci. 94:5405-5412. https://doi.org/10 $.3168 /$ jds.2010-3931.

Wellnitz, O., E. T. Arnold, M. Lehmann, and R. M. Bruckmaier. 2013. Short communication: Differential immunoglobulin transfer during mastitis challenge by pathogen-specific components. J. Dairy Sci. 96:1681-1684. https://doi.org/10.3168/jds.2012-6150.

Wellnitz, O., and D. E. Kerr. 2004. Cryopreserved bovine mammary cells to model epithelial response to infection. Vet. Immunol. Immunopathol. 101:191-202. https://doi.org/10.1016/j.vetimm.2004 .04 .019 .

Wellnitz, O., C. Zbinden, X. Huang, and R. M. Bruckmaier. 2016 Short communication: Differential loss of bovine mammary epithelial barrier integrity in response to lipopolysaccharide and lipoteichoic acid. J. Dairy Sci. 99:4851-4856. https://doi.org/10.3168/ jds.2016-10927. 